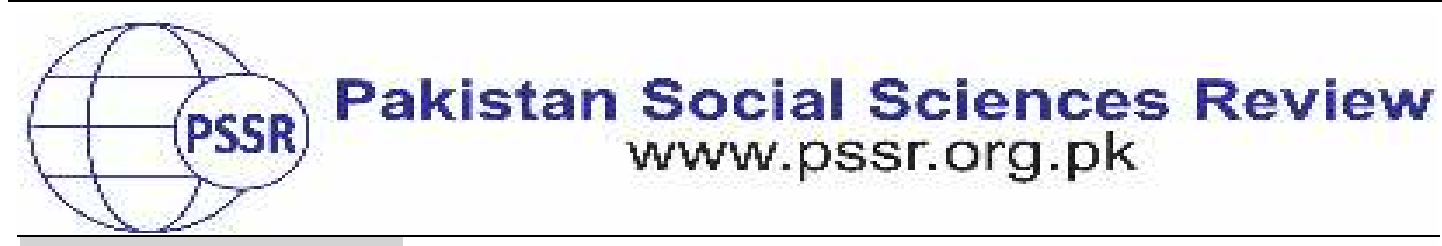

RESEARCH PAPER

\title{
A Narrative of Hybrid Identity of Second Generation Immigrants in 'The Buddha of Suburbia'
}

\section{Dr. Masroor Sibtain ${ }^{1}$ Junaid Mahmud*2 ${ }^{* 2}$ Muhammad Omer ${ }^{3}$}

1. Assistant Professor, Department of English, Government Graduate College of Science, Multan, Punjab, Pakistan

2. Assistant Professor, Department of English, Government Graduate College, Jhelum, Punjab, Pakistan

3. Lecturer, Department of English, Government Graduate College, Jhelum, Punjab, Pakistan

\begin{tabular}{|c|c|}
\hline PAP & $\Gamma$ \\
\hline $\begin{array}{l}\text { d: } \\
\text { 3, } 2021 \\
\text { d: } \\
29,2021 \\
\text { 31, } 2021\end{array}$ & $\begin{array}{l}\text { This study examines the difficulties experienced by second- } \\
\text { generation immigrants in establishing their identities as } \\
\text { depicted in Hanif Kureishi's "The Buddha of Suburbia." It seeks } \\
\text { to draw a comparison in identity creation between the } \\
\text { characters in this novel and general immigrants today, and how }\end{array}$ \\
\hline $\begin{array}{l}\text { Keywords: } \\
\text { Alienation, } \\
\text { Identity, } \\
\text { Intergenerational } \\
\text { Relationship, } \\
\text { Postcolonial Theory, } \\
\text { Racism, } \\
\text { Second-Generation } \\
\text { Immigrants }\end{array}$ & $\begin{array}{l}\text { racism, alienation, and intergenerational relationships all work } \\
\text { together to shape immigrants' identities in today's multicultural } \\
\text { environment applying postcolonial theory. Through thematic } \\
\text { analysis from a postmodern viewpoint employing character } \\
\text { analysis method, it confirms that a lack of sense of belonging is } \\
\text { a universal concern for immigrants everywhere today. The } \\
\text { novel's setting exposes a society transitioning to } \\
\text { postmodernism, which, among other characteristics, creates a }\end{array}$ \\
\hline $\begin{array}{l}\text { *Corresponding } \\
\text { Author }\end{array}$ & $\begin{array}{l}\text { sense of universal meaninglessness, and skepticism. All this } \\
\text { eventually gives genesis to the instability of identity as well as } \\
\text { a rise in rootlessness and alienation. This study is a humble } \\
\text { contribution to knowing the way second-generation } \\
\text { immigrants face problems of an identity crisis. }\end{array}$ \\
\hline
\end{tabular}

\section{Introduction}

The quest for identity in the postmodern scenario is very significant for the immigrants. The principal reasons for identity crisis for second-generation immigrants are racial discrimination, inter-generational confrontations among immigrants, multicultural society conflicts, and psychological agonies. The main focus here is on the formation of immigrant identity in a multicultural society. It would seek to expose how Karim and Haroon strive to explore their identity by facing the challenges that the immigrants face thus would provide the universal issues of immigrants. Kureishi does not restrict with Indian immigrants and their problems 
rather he has broadened the scope of his novel by making his characters reflecting a universal pattern. He very cleverly and cunningly selects the 1970's and 1980's for the novel since this was the era when immigrants in Britain were facing different social, cultural turbulence. Britain was herself trying to find her identity as postcolonial power. So the novel evolves the struggle of Karim as an immigrant toward his identity side by side. It also brings to light Britain's quest for identity. 'The Buddha of Suburbia' deals with the theme of identity in the multicultural and social prospect. The author depicts the racial discrimination, the inter-generation clashes of immigrants, and the conflicts of multicultural societies, the psychological agonies of second-generation immigrants in the 1970's of English society- a society replete with fashion, music and art. It is certain that the novel is featured in a particular historical background still its multidimensional themes offer a universal reading related to the identity problems faced by second-generation immigrants among the plethora of cultures. The novel highlights the quest for identity among non-western immigrants mostly from the former colonies. The novel relegates all those factors that these second-generation immigrants come across in their efforts of self-actualization. It also shows that the quest for identity even in the postmodern scenario is very significant for the immigrants. To understand all those elements and factors, we will use the character analysis method. This character analysis will unveil the themes of ethnicity, belonging, inter-generation relationships and conflicts of multiculturalism. By exposing these themes, we shall try to weave the identity of immigrants in the postmodern perspective of identity construction. We will apply postcolonial theory and postcolonial discourse to resolve the identity issue of the immigrants. We will see how the above-mentioned factors play important role in the process of hybridity which is the ultimate goal of the postmodern perspective. The mixture of concepts from the past and the present has given rise to a new foundation for socio-political identities. As a result, postcolonial theory, unfortunately, does not reproduce the old native culture, nor does it bring a new culture, but it produces a dislocated culture, a mixture of worlds - a "fragmented and hybrid theoretical language" within a "conflictual cultural interaction" (Young, 2001, p. 69 cf. Loomba, 1998, p. 15). We have found the answers to the following questions by sticking to the content analysis.

1. To what extent do the experiences of the main characters in The Buddha of Suburbia reflect the immigrant condition in the real world, and can their experiences be considered universal today?

2. How do the conditions of postmodern society affect the way how the individual shapes and negotiates identity?

3. What bearing does the social, cultural and ethnic background of an individual have on the process of identity formation, and how this contributes to or impedes a sense of belonging?

4. How can the conditions of The Buddha of Suburbia's main characters be considered representative of the immigrant experience in Western 
postmodern society?

\section{Literature Review}

After the decolonization, a large number of immigrants from former colonies such as Asia, Africa and the Caribbean came to England in the 1950s and 1960s and in 1970s and early 1980s, their number increased significantly by addition of secondgeneration immigrants. The youth among these people had certain anxiety of identity, the problem of belonging and conflict of their original ethnicity. Among them, some people began to write and to highlight these issues resulting in the birth of black British literature. Stein (2004) defines Black British literature-a central genre of black British literature- as the novel of transformation (p. 27). This genre works on two levels. On the one hand, the novel of transformation is about "subject formation under the influence of political, social, educational, familial, and other forces" (p. 22), and is thus related to the Bildungsroman. On the other hand, the novel of transformation addresses "the transformation of British society and cultural institutions". Moreover, he argues that "the novel of transformation not only portrays the change in British society and culture but, significantly, is also partly responsible for bringing about change" (p. 44). To understand the contribution of black British, it is essential to know that these writers fall into two categories: first-generation writers; who were optimistic and romantic in the beginning, aspired to Britain. Later, they were disillusioned when they saw the racial discrimination, the problem of finding jobs, homelessness etc. Another common theme among them was 'return'. They considered England their host where they could reside for some years to earn money for securing the future of their children. They felt their belonging to the area from where they came. They wanted to return home literally or mentally. The writers who fall in this category are Sam Selvon, V.S. Naipaul and George Lamming. Stein (2004) considers "return" ... a prevalent theme in post-colonial literature" (p. 57), and distinguishes between "actual, physical returning" on the one hand and "spiritual, notional, and intellectual returns" on the other hand. The intensity of the notion of 'return' in the second generation was not as intense as it was in the first generation writers. That was natural because the children did not have a direct link with their parents' homeland. But they were like a pendulum between England, the country of their birth and the country of their parents. They remained in the confusion of belonging and un-belonging. D' Aguiar (2000), the second generation writer, writes in his essay, "Home is Always Elsewhere," says, London was spoiled for me by my belief that one day I would return to Guyana, and when that was no longer true, by a feeling that London did not belong to me, could never belong to me on account of my race, my minority status. A white majority made me aware daily that I was a visitor, a guest." According to him, the notion of 'return' is false, so the secondgeneration authors stress upon finding the place in the British culture and constructing the identity of their own. But they were confused when they faced the attitude of Otherness in British society. The Britishers took them as visitors and guests 
etc. These writers focused upon how the second generation could resolve the issue of ethnicity.

The second generation faces the trauma of choices whether they should join themselves with their ancestral culture or they should immerse themselves within the culture of their birthplace. These writers suggested going for the latter choice. They also highlighted problems that the second generation children could face when they would try to link themselves with British culture. D' Aguiar (2000) argues that one's place and position in one's society affects his or her identity and 'allegiances are shifting.' (p. 200), as is his identity: "I saw myself splinter across these landscapes and multiply into plural selves"(p. 203). According to him, identity is unfixed; it can be created in a multicultural society. This very dictum has been the special concern of second-generation writers such as Caryle Phillips and Hanif Kureishi. Second generation writers mostly coined the theme of gender, cross-cultural conflict, intergeneration conflicts and gaps etc. All these novels like Ravinder Randhawa's $A$ Wicked Old Man(1987), Meera Syal's Anita and Me (1996), Monica Ali's Brick Lane (2003), Andrea Levy's Never Far from Nowhere (1996), Fruit of the Lemon (1999), Fred D'Aguiar's The Longest Memory (1994), Feeding the Ghosts (1997), Caryle Phillips' Cambridge (1991) discuss and portray the immigrants confronting with ethnic, cultural, social, psychological and political issues in Britain. Though these novels represent different historical backgrounds yet we find a parallel affinity between them since on the one hand, they portray the second-generation-immigrants; on the other hand, they have neglected to go back to their ancestral homeland. These novels deal with the hybridity in the construction of identity. 'The Buddha of Suburbia' contains in it the cultural clashes, the inter-generational conflict and mixed-race identities. The selected work has been chosen for two reasons, firstl, it covers not only the second generation immigrants but also discusses the mixed-blood generation, it broadens the scope of research, it would enable me to take this research from particular to the general. We would try to link the problems faced by secondgeneration immigrants; Karim and Jamila with immigrants all over the world. Secondly, the novel not only discusses racial discrimination and its consequences with an individual but also studies an individual's entangling with his family who fails to provide him with the identity by constructing his 'self' in a particular construct, therefore, Karim has to generate his self. Thus he falls into the postmodern scenario for his identity and survival.

\section{Theoretical and Methodological Framework}

The lens of Postcolonial theory is used in this research to view the process of identity, redemption and evolution of the protagonist in the novel 'The Buddha of Suburbia'. Before discussing the particular factors and angles of the post-colonial theory that we will use to analyze the selected piece of literature we consider it essential to define what postcolonial theory and literature are. Generally, postcolonial 
literature means the writing of those writers who got freedom from colonial powers. But on a broader scope, the literature that has been written in the colonial period can also be considered a part of postcolonial literature. The postcolonial theorists try to assess how postcolonial writers generate their discourse by dismantling the previous discourses given by colonial powers. The theorists also try to analyze the response of the colonized after their decolonization. According to Bhabha (2012), postcolonial means 'Postcolonial perspectives emerge from the colonial testimony of Third World countries and the discourses of "minorities" within the geopolitical divisions of East and West, North and South. They intervene in those ideological discourses of modernity that attempt to give a hegemonic "normality" to the uneven development and the differential, often disadvantaged, histories of nations, races, communities, peoples. According to Young (2001), postcolonial theory as a "political discourse" emerged mainly from experiences of oppression and struggles for freedom after the "tricontinental" awakening in Africa, Asia and Latin America: the continents associated with poverty and conflict. Postcolonial criticism focuses on the oppression and coercive domination that operate in the contemporary world (Young, 2001). The focus of this research would be the problem of identity in the first and secondgeneration immigrants in Britain. The immigrant writers who write for this cause are called black British writers. First of all, we will use their theoretical framework then we would like to attach this identity problem with postmodern sociological and psychological theories.

As mentioned above, the presence of immigrants in Britain was influential on both the social and academic levels. However, it was not only British society that changed under the mass-migration trend but also the immigrants themselves were subject to change under their new conditions. The British environment in which the immigrants arrived contained sometimes very diverging or even colliding social and cultural norms compared with the ones they were used to in their home country. As a consequence, the immigrants had to reconsider their cultural affiliations and consciously decide to what extent they were to assimilate into the British lifestyle or to preserve aspects that belong to their original culture. Bhabha (2012) explains that "terms of cultural engagement, whether antagonistic or affiliative, are produced "performatively" (p.2), thereby emphasizing the conscious choices immigrants have to make in their new environment. The performance of cultural affiliation affects the immigrants' position towards their homeland, original culture and ethnicity.

One generation later, the children of these immigrants face a very different situation. This second-generation can no longer consider their parents' homeland, their home country. Since they were born and raised in Britain, their affiliation with the country of origin is even more complicated than their parents". In the introduction to Black British Culture E Society, Owusu (2003) describes the situation of the second generation in contrast to that of their parents and emphasizes the problematic status of the notion of 'home' in immigrant families: "Unlike their 
parents, the second generation of Black youth did not see themselves as "temporary guests" of Her Majesty's government. They were not here to work and eventually return "home" to the Caribbean or Africa. Britain was their home, and ... they were, here to stay!" (p. 9). The relationship of the second generation to Britain is very different from that of their parents, but, in its way, also problematic, because the children of immigrants are not seen as straightforwardly belonging to the country in which they were born. Mostly regarded "as foreigners, as interlopers in the land of their birth" (Stein, 2004, p. 42), the second-generation immigrants experience particular and complex affiliations with Britain. Paul Gilroy describes the situation of second-generation immigrants in England as follows: "The contemporary black English stands between (at least) two great cultural assemblages" (p. 439). On the one hand, this generation is influenced by their parents "culture and ethnic heritage, while, on the other hand, it grows up in a society with a wholly different predominant culture.

This "in-between" situation profoundly affects the second generation's construction of identity. Identity construction can be subdivided, despite considerable overlaps, into three categories: national, cultural, and ethnic identity. With regard to national identity, the children of immigrants can be considered as having a British national identity. They were born on British soil, and the concept of Britishness is, according to Goldsworthy (1999), "based on the civic idea of nationality" (p.96), even though she adds that "[a] foreign name, a foreign accent, different skin colour, all seem to imply "hyphenated "Britishness" (p. 96). The other types of identity are not so easily determined, especially not in the context of migration. Cultural identity is an extremely fluid concept in contemporary reality its fluidity is not to be restricted to immigrants and their descendants - with people choosing to take on certain cultural aspects and consciously distancing themselves from others. Cultural identity is, as Hall (2002) mentions, "not fixed, it's always hybrid". With regard to ethnic identity, the notion of hybridity can also be applied, but in this case, it is more applicable to migrant contexts. Second-generation immigrants consciously have to decide how they will position themselves towards their inherited ethnicity, on the one hand, and towards the predominant ethnicity in their environment of upbringing on the other hand. The two ethnicities are not mutually exclusive, but they allow hybrid constructs, dependent, among other things, on the second generation immigrant's attitude towards his/her ethnic heritage and their affiliation with native birth place. In the rest of this dissertation, we will analyze which cultural aspects, British or the other, the characters belonging to the second generation adopt in the establishment of their cultural identity, and discuss how they regard their ethnicity.

The concept of ethnicity plays a considerable role in one's identity construction. Hall (2002) emphasizes this role by stating that "the term ethnicity acknowledges the place of history, language and culture in the construction of 
subjectivity and identity ..." . Because of the explicit link between an immigrant's identity and his/her ethnicity, the latter can be considered a concept of considerable importance in the context of migration, and, accordingly, has attracted much scholarly attention in the postcolonial period. Yet, although "[e]thnicity is a term that has been used increasingly since the 1960s" (Ashcroft et. al. 2013), it has no fixed definition. The exact elements which constitute the term are variable. For example, the extent to which the notion "race" occupies a place in the concept of "ethnicity" is arguable, considered an aspect of ethnicity by some scholars, whereas others define it as a separate category (Sollors, 1986). By stating that "ethnicity acknowledges the place of history, language and culture in the construction of . . . identity" (Hall, 2002,p. 226), he further indicates that the term comprises different factors. Sollors (1986) summarizes the different conceptions by stating that ethnicity is "a broadly conceived term." (p.222). A more specific working definition can be found in PostColonial Studies: The Key Concepts, in which the term ethnicity "account[s] for human variation in terms of culture, tradition, language, social patterns and ancestry . .." Furthermore, they specify the concept of "ethnicity "e by enumerating " "the symbolic elements" that may provide a sense of ethnic belonging", more particularly "kinship patterns, physical contiguity, religious affiliation, language or dialect forms, tribal affiliation, nationality, physical features, cultural values, and cultural practices such as art, literature and music" (p.84). In the present study, we will analyze which aspects the characters of The Buddha of Suburbia include in the constitution of their ethnic identity, and discuss the extent to which they consider their race an important factor. In the next step, we would try to analyze the construction and evolution of identity by using postmodern theory, in this, we will follow Sardar's (1998) framework on postmodernism where he sees this deconstruction process as leading to the fourth (of five) 'principles of postmodernism' (p.197), which will be elaborated further in the next section. What he means by principles of postmodernism is that five main (negative) traits define postmodern society which is all a consequence of "a number of key intellectual and social developments which have undermined modernity" (p.198). Among others, these developments include: i) "The demystification of scientific objectivity; ii) The collapse of Western philosophy; iii) The emphasis on indeterminacy in quantum physics and mathematics; iv) The emphasis on discontinuity and difference in history; v) The concern over the 'Other' in history, anthropology and politics; vi) The secularization process of Christianity and its removal from society as a moral force; And vii) the triumph of the market economy and the emergence of the pathological concern with consumer 'choice."

Sardar (1998) argues that "postmodernism has thus penetrated all spheres of disciplinary thought, established deep roots in daily life while becoming a global cultural force underpinned by [the] free market" (p. 200). In other words, these simultaneous developments have completely deconstructed modern society and replaced it with postmodern society. According to him, the consequences of this are as follows: 
a) Old truths are no longer valid

b) Complete denial of reality

c) Creation of simulacrums

d) Total meaninglessness

e) Doubt in everything

This postmodernism further opens the discussion on the formation of multiphrenic self, the role of class and ultimate subaltern identity. We will follow the method of content analysis to find out the answers to research questions, our focus will be upon the text of The Buddha of Suburbia by Hanif Kureishi.

\section{Discussion}

Stein (2004) terms the fiction of second generation as 'novel of formation.' The Buddha of Suburbia is a true novel of formation. It is about the son of an Indian born father and a lower-middle-class mother. The novel deals with their values and clashes, the role of the family in bringing up the immigrant child. The novel also discusses alienation, belonging and un-belonging to transform the identity of KarimHaroon's son- who migrated to England from India in the early 1950s. Haroon never went back, so Karim did not visit India. They were living in the suburbs of London. Karim was not satisfied with his condition. His father had ambitious dreams for Karim's future. Kureishi highlights the quest for identity and the problem of identity right at the beginning of the novel. His selection of first-person narrative makes the identity theme more sublime. Karim himself utters his identity as he introduces himself in the novel: "I am an Englishman born and bred, almost. I am often considered to be a funny kind of Englishman, a new breed as it were, having emerged from two old histories, the odd mixture of continents and blood, of here and there, of belonging and not" (p.3). Being a teenager he neither feels proud of being Indian nor feels shy and ashamed of his identity. He considers himself a part of the culture and enjoys every ingredient of English culture. The only racism he encounters in his teenage is at the hands of his schoolmates in the playground; still, he does not feel much disturbed. Later on, London opens his eyes to this context. In his teenage, it is not just racism with which he has to cope with his major issue is his maladjustment in a suburb. For his father suburb offers great opportunities to excel through education. In reality, the institutions of suburbs produce middle-class servants. Karim aspires to join his uncle and aunt who have left the suburb and its life. They are indulged in parties, functions and art etc. for Karim this life pattern is a success. Therefore Karim dislikes suburbs, for him suburb is a restriction, boredom and isolation. He loves London. The city represents hope, discovery, opportunity and excitement, and "thousands of black people everywhere, so [he] wouldn't feel exposed" (p.121). When Karim goes to London especially in theatre, he realizes that he cannot compete with these people as he lacks currency and capital. While his 
"authenticity" is his ticket in, he can never compete with "people who wrote books as naturally as we played football. The easy talk of art, theatre, architecture, travel; the languages, the vocabulary, knowing the way round a whole culture - it was invaluable and irreplaceable capital"(p. 177). Karim never participated in the cultural activities of his father's culture. He did not experience going to the mosque or of discrimination of Halal and Haram food. The only fragment that Karim had from Indian culture is the youth stories of his father Haroon and the friend of his father, Anwer. Therefore Karim can see and analyze both these cultures impartially. He never achieves wholeness in either of the cultures. Karim's external identity appears a slap for him as he is never looked upon as English. He is taken as non-English wherever he goes. He is not judged by what he is rather he is judged by what he is not. This thing develops in Karim a feeling that leads to the quest for identity. First, Karim denies performing the role described by class and society, later on, he plays and wins the admiration as he does not feel any embarrassment of his identity, and he tries to win his authenticity by performing the role of an Indian boy. Shadwell remarks about him, it is Karim's “destiny to be a half-caste in England ......belonging nowhere, wanted nowhere" (p.54). In the beginning, Karim offends these remarks bet then realizes that these remarks are true. "The immigrant is the Everyman of the twentieth century.... What a breed of people two hundred years of imperialism has given birth to. ...... Everyone looks at you, I'm sure, and thinks: an Indian boy, how exotic, how interesting, what stories of aunties and elephants we'll hear now from him. And you're from Orpington"(p.141). It is Karim's school that makes him experience Racism and Otherness. His schoolmates call him 'shitface' and 'curryface'. Karim considers himself lucky when he returns home without a serious injury. These events enable Karim to realize he would not be able to fulfil the dreams of his father in this suffocated suburb. Karim is forced to feel Otherness. In the third chapter, Karim is chased off by Helen's father who is the girlfriend of Karim. Hairy Back looses the dog upon him and says: "However many niggers there are, we don't like it. We're with Enoch" (p.40). Hairy Back represents the British parliamentarian who spoke against the immigration of African and Asian people and the indiscriminating legislation in his speech "Rivers of Blood". This terrible and comic loosening of dogs is the extended metaphor for the cruel treatment meted out to immigrants at the hands of their ex-masters. When Karim visits Jamila, he feels relaxed because he finds the poor town of Jamila more victimized by threats of racism. They think that some of these white may kill one of them, which is "inspired by the possibility that a white group might kill one of us one day". In such circumstances, Karim and Jamila play with their identities as Karim says: "Yeah, sometimes we were French, Jammie and I, and other times we went black American. The thing was, "we were supposed to be English, but to the English, we were always wogs and nigs and pakis and the rest of it" (p.53). This external racism destroys the inner self of Karim by creating a sense of alienation in him. He realizes that his colour of the skin will be a source of mockery and exploitation for the white. Karim realizes that they impose an identity on them when he is given the role of an Indian in the novel Kipling. He accepts and limits 
himself professionally. Later on, he performs the role of new immigrant Indian representing Changez, the imported husband of Jamila. Later he manages to gain a role of "a rebellious student son of an Indian shopkeeper" (p. 259). In a new television soap opera "that tangled with the latest contemporary issues ... such as .... abortions and racist attacks..."(p. 259). Hanif cleverly chooses the first role from Kipling's Mowgli. It gives the stereotyped picture of the imperialist. Jamila considers it neofascism, Karim's father rightly sums up: "That bloody fucker Mr Kipling pretending to whity he knew something about India!" (p. 157). Karim's experience of racism can be understood in the light of the experience of Gene, a black nigger, Eleanor's "black lover, London's best mime, who emptied bed-pans in hospital soaps, [who] killed himself because every day, by a look, a remark, an attitude, the English told him they hated him; they never let him forget they thought him a nigger, a slave, a lower being" (p.227). Though Karim is a hard-working professional actor, he feels conflicts of ethnicity when white people impose upon him certain characters. Their interest in such characters as performed by Karim is the harmony between the character and Karim. Karim does not feel it; he takes it as a professional task. At the final stages of the novel, Karim experiences white stereotyped racism when he watches a Negro group of people performing in New York. Here Karim feels himself a colonizer watching the performance of the colonized. It is not just racism that plays an important role in the construction of identity of Karim. Class is another major factor in in the identity process. Karim's class is marginalized and he is well-conscious of it. Again the marginalization of classes is clearly shown in Karim's schools. He attends Secondary Model School which focuses to train labourers for practical purposes only. He does not like the 11+ examination system which decides who will for the university education and who ill for the SS. These decisions are made in accordance with the classes. The failure of this exam is permanently labeled as a failure. Karim realizes that British is still a class-ridden society: "Fuck you, Charles Dickens, nothing's changed" (p. 63). Karim strives to win the permanent membership of exclusive theatre and club through merit but his natural environment such as family suburb and school are barren. They cannot help him as Karim says for those British writers: The "hard words and sophisticated ideas that were in the air they breathed from birth..... could only ever be a second language, consciously acquired" (p.178).

Tracing identity, it is seen that both racism and class distinctions go side by side. Karim's family and relations play the role of springboard in his evolution. He finds himself a member of three different families; the first family is a traditional family consisting of Karim's mother, father and his younger. This is a routine family, Karim considers it boredom. For Karim it is just net: "(...) things were so gloomy, so slow and heavy, in our family (...) Quite frankly, it was all getting me down and I was ready for anything" (p.3). This family plays two important roles in Karim's identity: first of all, it is the family's suffocating atmosphere that compels Karim to leave his house and to go to London to search for his identity. Secondly, when his father leaves his mother and goes to Eva, he frees himself from the power and 
domination of his father. He also uses Eva to go to the higher classes. The second family is the family of Anwer, a friend of his father, Jeeta and Jamila. This family Karim uses for catharsis. He discusses everything with Jamila and feels relieved. Jamila's husband Changez makes Karim believe and feel that Changez is Indian and he is English. Karim has to leave this family as well for two reasons. First of all, Karim cannot go to London without breaking with this family, secondly, Anwer's revival towards Muslim culture makes him leave the family. The third family with which Karim links himself is Eva and her son Charlie. Karim has contradictory feelings and emotions toward this family. Karim uses Eva to reach London; therefore, Eva is a source of escape from the slums of a suburb. On the other hand, he considers Eva the real cause of the disintegration of his family. Charlie replaces Karim's father as a guide for Karim. He introduces new fashion, theatre to Karim. It is Charlie who takes Karim to New York with him. Thus this third family opens up new gates of opportunity for Karim. All three families shape his views, the moral problem is never there with Karim throughout the novel. We find him self-centred, selfish and a liar. He is unscruplous in stealing, in breaking promises and breaking trusts etc. one thing that is quite sublime in his character is that he is well-aware of his moral weaknesses." (p. 178).

To understand the evolution of Karim's identity, one has to consider his father's experiences as immigrant facing racism, ethnicity in order to find the smallest space in British society. Haroon, his father, belongs to $1^{\text {st }}$ generation immigrants who are more Indian This first-generation immigrant seeks their identity by undergoing a cultural transformation side by side with adhering to their native land and turning into both an economic as well as social outcast."(p.64). Haroon appears as a passive character, still, throughout the novel, he keeps on dreaming to find belonging and acceptance. He tries to improve his language but the real satisfaction he gets when he realizes that being an immigrant he cannot find belonging and identity with money, education or such things. He can do it by reading himself, he begins to teach to find peace of mind; he begins to feel superior when he becomes a 'guru'. He wants to gain something through his son by making him a doctor; again he fails to do it. The only belonging he manages when he returns to Orientalism: "Dad always felt superior to the British: this was the legacy of his Indian childhood-political anger turning into scorn and contemp." (p. 284). Having undergone hybridity in outlook and behavioral conflict, Haroon has liberated himself from the house and boredom which eventually provides Karim freedom, it is Eva who caused Haroon's movement that leads Karim to independence. Thus in the end, both remain in confusion whether they have found the aspired identity and equality and still they have to face Otherness.

The Buddha of Suburbia deals definitely with identity crisis. Postmodern theorists like Sardar (1998) however discard the concept of modern age identity as believing in core identity. They believe in several concurrent identities. Karim's 
character is a sign of postmodern identity. He has to interact with different social institutions such as his family, theatre, sexual interactions etc. this ability to cope with different interactional identities form a narrative of postmodern identity. Gergen's (1991) theory on the multiphrenic-self can fit well to the main characters of The Buddha of Suburbia. According to him, it is not just interactional dialogue rather these interactional dialogues that create many thoughts in one's mind. These thoughts generate many relations; imaginative and real and these thoughts and relations constitute multiphrenic self.

We find Karim juggling with many identities when he joins theater, when he and Jamila meet in their teenage when he goes to New York. On the other hand, some characters construct multiphrenic selves but do not retain it as Anthony observes: Though we do see traces of the multiphrenic self through the characters in the novel, it can also be argued that some characters are not multiphrenic, but rather create, delete and recreate their biographical narratives as suggested by Giddens (1991). The concept of Creolisation is also important in the concept of identity when we read it in the postmodern paradigm of identity. The term 'Creole' has come from the $16^{\text {th }}$ century colonial period. It was used for the offshoot of colonizers in their colonies. Initially, the term had negative connotations but later on, it is reversed. Now it is taken as continual negotiation between multi interactional dialogues to find a place. We find many examples of creolisation in this novel. For instance, Jamila and Karim go for French and Black American identity; similarly, Haroon negotiates and adopts the role of Buddha. The negotiation is not limited between the characters' selves but it is the negotiation of two cultures in a multicultural society.

Belonging as a very important construct in shaping identity, is a higher need than food and drink. It gives meaning to one's life and serves as a mirror through which one can see. Karim belongs to Eva because of his sexual desire and emotional satisfaction with her son. Charlie proves a guide for him. Karim's affair with an actress provides him with belonging to western culture. Karim's affiliation with Jamila helps him to face the status of non-English. It is his belonging with Indians that Karim blames his father for keeping him away from India. The concept of belonging is also very significant in Haroon's case. Belonging is a very basic human need. In his 'hierarchy of needs, he argues that the need for social relations, appreciation by others and belongingness is stronger than physical needs such as food and safety. Asian immigrants feel alienated mostly due to their sense of belonging, Otherness and estrangement in the western society. This belonging enables him to face continual change which is the essential part of identity in the postmodern age. Karim finds his identity when he leaves to depend upon Charlie and Pyke, he is ready for the continued change. Haroon also reinforces his identity by accepting the role of the Buddha of suburbia. In this way, Kureishi generalizes the problems of immigrants who feel quest for identity, since identity is not fixed in postmodern society, the immigrant should learn to cope with the changes. Similarly, the host country should 
also change its attitude.

\section{Conclusion}

This article aimed to investigate the universality of the immigrant experience portrayed in The Buddha of Suburbia. Literary analysis was carried out to identify the central themes of the novel. It was found out that the novel fulfilled much of the criteria of the Bildungsroman and this then allowed us to use the central elements of the genre in our analysis of Karim and Haroon. We may rightly conclude that identity, class, belonging, alienation, multiculturalism, and the immigrant experience are the key themes which have been analyzed from a postmodern perspective on the assumption that a person's identity is created both from within and without. The setting of the novel is a society in transition to postmodernism, which along with other traits, generates a state of general meaninglessness, doubt and a lack of Grand Narratives with a destabilization of identity along with increased rootlessness and alienation as a natural concomitant. In tandem with these changes in society, identity has become more dependent on interactional dialogue. The view that identity has a stable core has been replaced by the notion that a person has multiple identities which are in a state of constant change. Despite the rapid demographic shift experienced by British society, the debate on nationalism, culture and ethnicity is still ongoing today as the first and second-generation immigrants still feature heavily in public discourse. Covertly, these groups are still perceived as the 'others' or the out-group, defined by the in-group not by what they are, but by what they are not. 


\section{References}

Ashcroft, B., Griffiths, G., \& Tiffin, H. (2013). Post-colonial studies: The key concepts. Routledge.

Bhabha, H. K. (2012). The Location of Culture. Routledge.

D'Aguiar, F. (2000). Home is always elsewhere: individual and communal regenerative capacities of loss. Black British culture and society, 195-206.

Gergen, K. J. (1991). The saturated self: Dilemmas of identity in modern life. New York, America: Basic Books.

Giddens, A. (1991). Modernity and self-identity: Self and society in the late modern age. Stanford university press.

Goldsworthy, V. (1999). The last stop on the Orient Express: the Balkans and the politics of British in (ter) vention. Balkanologie. Revue d'études pluridisciplinaires, 3(2). 1-7

Kureishi, H. (1991). The Buddha of Suburbia. Faber and Faber Limited.

Loomba, A. (1998). Colonialism/postcolonialism. Routledge.

Owusu, K. (Ed.). (2003). Black British culture and society: A text reader. Routledge.

Sardar, Z. (1998). Postmodernism and the other: New imperialism of western culture. Pluto Press.

Stein, M. (2004). Black British literature: novels of transformation. Ohio State University Press.

Young, R. J. (2001). Postcolonialism: An historical introduction. Blackwell. 383-426 